\title{
O autor como personagem de si mesmo na série Minha Luta de Karl Ove Knausgård"
}

\section{Artigo Livre}

* Recebido em: 19.10.2018. Aprovado em: 23.12.2018.

** Doutorando em Sociologia pela Universidade de Brasília (UNB) Email:antonio.padua.brito@gmail.com
Resumo: O presente artigo tem por objetivo apresentar uma discussão sobre o contexto da recepção da série Minha Luta, do escritor norueguês Karl Ove Knausgård, e contribuir com o debate sobre a proliferação recente de romances realistas, que tratam de fatos e situações reais, e o porquê da boa recepção dos leitores a esse tipo de linguagem na contemporaneidade. Pelo caráter memorialista e fragmentado da série de seis livros, o autor tem sido apontado como um representante paradigmático de um tipo de realismo denominado de "autoficção", no qual abdica-se da pretensão de abarcar uma totalidade, optando por um relato parcial e aparentemente insignificante das próprias vidas, apresentando para os leitores uma descrição minuciosa de fatos, gestos e objetos do cotidiano. A revalorização do realismo refuta hipóteses acerca do esgotamento do gênero romance por este se conformar a relatos cada vez mais descritivos, abdicando de interpretações totalizantes do mundo.

Palavras-Chave: Romance, Realismo, Autoficção; Real; Karl Ove Knausgård
Abstract: This article aims to present a discussion on the context of the reception of the Norwegian writer Karl Ove Knausgård's Minha Luta series, and to contribute to the debate on the recent proliferation of realistic novels dealing with real facts and situations, and why the readers welcome this type of language in contemporary times. Due to the fragmented and memorialistic character of the six-book series, the author has been appointed as a paradigmatic representative of a type of realism called "selffiction", in which he abdicates the claim to embrace a totality, opting for a partial and apparently insignificant of their own lives, presenting to the readers a thorough description of everyday facts, gestures and objects. The revaluation of realism refutes hypotheses about the exhaustion of the novel genre as it conforms to increasingly descriptive accounts, abdicating totalizing interpretations of the world.

Keywords: Romance, Realism, Self-Fiction; Real; Karl Ove Knausgård 


\section{Introdução}

Os métodos sociológicos, quando aplicados à literatura, costumam ser orientados para uma interpretação da obra literária como um modo de representação da realidade. Por tal perspectiva, os estudos costumam ser, de um lado, direcionados no sentido de compreender como uma literatura nacional se articula com a história ou com a identidade de um país. Outros, por uma vertente pósmoderna, voltam-se para as identidades específicas dos autores e como eles se fazem representar nas obras a partir dos seus "lugares de fala", o que, em alguma medida, é uma forma de representação de uma realidade em particular.

Entretanto, mais do que representar a realidade, uma obra de literária, assim como qualquer obra de arte, é uma criação, ou, mais precisamente, uma fantasia que obviamente não está desprendida da realidade, mas que vai além, uma vez que, por meio dessa fantasia, o autor "cria mundos", entrevendo "uma saída para o Real" (BARTHES, 2005, p. 31).

Se assim for, o que dizer da literatura de viés realista ou, mais especificamente, dos relatos memorialistas e do jornalismo literário, cuja pretensão de vínculo com o real é mais evidente?

Também nesse caso, pode-se considerar que prevalece o ficcional e, consequentemente, a fantasia, pois nenhuma memória é total. Passado o instante em que os fatos ocorrem, nenhum dos protagonistas ou testemunha desses fatos é capaz de retê-los na sua a totalidade. Em qualquer episódio das nossas vidas, por melhor que seja a nossa memória, somos incapazes de reter a totalidade do que vivemos: sempre teremos uma perspectiva fragmentada, incompleta e não linear dos acontecimentos, aspectos que se reforçam ainda mais com o transcorrer do tempo. Além disso, mesmo quando as memórias são registradas a partir de relatos de terceiros, como acontece no jornalismo literário, ainda assim não é possível ter um registro exato do ocorrido por maiores que sejam os esforços de reportagem e o número de depoimentos coletados, uma vez que as perspectivas possíveis para abarcar a totalidade de qualquer evento são infinitas e o universo de observadores é finito, constituído de sujeitos imaginativos, com capacidade nata de distorcer e recriar a própria memória a partir de elementos psíquicos da própria subjetividade.

Assim sendo, pode-se inferir que uma narrativa memorialista, jornalístico-literária ou meramente literária, baseia-se em narrativas dispersas e fragmentadas, intercaladas por vazios de memória os quais são preenchidos e alinhavados pela imaginação e, consequentemente, pela ficção. Pode-se então afirmar que as formas narrativas baseadas no "real" são, em última instância, ficcionais, uma vez que a fantasia, aquilo que é imaginado pelo autor e que dá sentido à narrativa, acaba se constituindo como a matéria-prima para a "reinvenção" da memória. Não por outra razão, Roland Barthes (2005), ao declarar a sua preferência literária por romances de memória, afirma que "na verdade, não é a memória que é criadora (de Romance), é a sua deformação" (BARTHES, 2005, p. $32)$. 
${ }^{1} \mathrm{O}$ termo realismo aqui utilizado não se refere especificamente ao movimento literário do século XIX, mas à forma mais geral de representação da realidade na obra de arte sem utilização primordial de recursos estilísticos alegóricos, surrealistas ou abstratos.

Dossiê Consumo e Subjetividade

Arquivos do CMD, Volume7, N.2. AGo/Dez 2018
Tendo como base essa perspectiva, o objetivo do presente artigo é apresentar uma breve análise da série Minha Luta do escritor norueguês Karl Ove Knausgård, romance de caráter autoficcional, distribuído em seis tomos que foram publicados entre 2009-2011, totalizando mais de 3000 páginas escritas. Trata-se de uma obra que repercutiu fortemente no mercado literário global ao longo dos últimos anos, tendo amealhado uma respeitável fortuna crítica. Ao longo da série, Knausgård faz um relato fragmentado (não cronológico) da sua própria vida, recuperando memórias, em grande parte recriadas, como ele próprio admite, que vão da infância até o exato momento (o "instante já") da escrita. Dado o grande alcance de público e crítica da série, e também por estar longe de ser um fenômeno isolado, considerando que são muitos exemplos recentes de relatos memorialistas e autoficcionais que vêm despontando no mercado literário, trata-se de uma obra paradigmática para se analisar as fronteiras do real e os mecanismos ficcionais de recriação da memória, uma oportunidade de identificação da forma psíquica de um autor em particular (Knausgård, no caso), e a maneira como ele articula sua subjetividade por meio do romance.

Para tal, o presente artigo está dividido em três tópicos, além desta introdução e das considerações finais. No primeiro tópico, será feita uma breve apresentação do "ressurgimento" do realismo na produção literária das últimas duas décadas, refutando, em certa medida, os prognósticos que sugeriam o esgotamento do romance justamente pela sua incapacidade de se desvencilhar do realismo.
No segundo tópico, será analisada a questão do realismo em Lukács e como a figura do herói cindido entre o idealismo e o real é construída na forma romanesca. No terceiro tópico, serão apresentados aspectos específicos da obra, referenciando as principais influências reveladas pelo autor e em que contextos ele passou a se reconhecer como um criador.

\section{Os anos 2000 e a emergência do real.}

Em uma entrevista recente para a Folha de São Paulo, por ocasião do lançamento do livro Mutações da literatura - século XXI, a crítica literária Leyla Perrone Moisés (2017) afirmou que "a busca pelo realismo permanece intensa" entre os escritores ${ }^{1}$. Uma perspectiva panorâmica sobre a produção literária atual corrobora essa hipótese, pois são muitas as obras destacadas recentemente que apelam para artifícios realistas.

Além do próprio Knausgård, é possível citar Elena Ferrante, pseudônimo de uma escritora italiana cuja identidade é mantida em segredo, com a sua "tetralogia napolitana", que remete às suas memórias pessoais da infância à vida adulta na cidade de Nápoles. Há também o caso de Édouard Louis, jovem escritor francês que, na obra de estreia ( $O$ fim de Eddy), faz um relato da sua infância no interior da França e as vicissitudes da descoberta da própria homossexualidade em um ambiente extremamente repressor, permeado, além de tudo, por uma condição social de fome e pobreza. 
2 "Svetlana Alexievich vence Novel de Literatura de 2015". G1, 08 out. 2015. Disponível em:< http://g1.globo.com/poparte/noticia/2015/10/svetlanaalexievich-nobel-de-literatura-teralivros-editados-no-brasil.html>. Acesso em: 30 ago. 2015.
Outros bons exemplos de narrativas realistas são o de Chimamanda Adichie (Hibisco roxo), nigeriana radicada nos EUA, de Ishmael Beah (Muito longe de casa), uma ex-criança soldado Serra-leonense também residente nos EUA, e de Scholastique Mukasonga (A mulher de pés descalços) e Gael Faye (Meu pequeno país), ambos sobreviventes do genocídio ruandês e atualmente residentes na França. Há ainda as escritoras Isabela Figueiredo (Cadernos de Memória Colonial) e Dulce Maria Cardoso ( $O$ Retorno), a primeira de origem moçambicana e a segunda, angolana, ambas filhas de portugueses retornados à "metrópole" após os movimentos de libertação e guerras civis dessas duas excolônias portuguesas na África, e que narram as memórias dos tempos da vida nas colônias e os traumas do retorno.

Todos esses são exemplos de autores marcados pela experiência da diáspora, cujos romances revelam vivências trágicas na infância, por meio de narrativas pouco ou nada alegóricas, mais ficcionais, no caso de Chimamanda e Dulce Cardoso, ou mais memorialistas, no caso dos demais, uma geração de escritores formada por muitas mulheres nascidas em países africanos cujas obras remetem às suas experiências particulares como mulheres (algumas negras), imigrantes e desterradas, refletindo sobre o estranhamento e as dificuldades de reconhecimento, tanto em relação aos lugares de origem como em relação aos centros globais para onde se deslocaram e se estabeleceram, em face das diversas formas de preconceito (raciais, de gênero, etc) e de violência.
No Brasil, há também bons exemplos literários recentes de linguagem realista ou pautada em memórias, dentre os quais é possível citar desde Cidade de Deus, de Paulo Lins, até as obras recentes de Michel Laub (O Tribunal da Quinta-Feira), Bernardo Carvalho (Reprodução), Cristóvão Tezza (O Filho Eterno) e jovem escritor Geovane Martins ( $O$ sol na cabeça).

Além disso, vale ainda destacar como marco da "emergência do realismo", mas pela vertente do jornalismo, o prêmio Nobel concedido em 2015 à bielorrussa Svetlana Alexijevic, cuja obra ainda que se baseie em depoimentos reais de mulheres e homens soviéticos e pós-soviéticos que vivenciaram ou sofreram as consequências de catástrofes dos momentos mais dramáticos da história daquele mundo, tais como o desastre de Chernobyl, a Segunda Grande Guerra e a Guerra do Afeganistão - possui características ficcionais pelo fato de a autora procurar contar não a "história dos fatos, mas a história das almas" 2

Vale destacar que a emergência do realismo nas últimas décadas não se deu exclusivamente da literatura. Segmentos importantes das artes plásticas vêm trilhando, desde os anos 1960, uma trajetória alinhada com o realismo, caso da arte pop e do hiperrealismo (FOSTER, 2014).

Em todos esses casos, ainda que fatos reais, memórias, noticiário e vivências pessoais se constituam como a matéria-prima das narrativas, o resultado não é (nem é desejável que seja) um retrato fiel e total da realidade. Trata-se de um pressuposto discutível, mas aplicável até mesmo a trabalhos estritamente 
jornalísticos e acadêmicos do campo histórico, pelo fato da linguagem, que não contém o referente, ser um código autorreferencial de representação do real (FOSTER, 2014).

Ademais, o objetivo último dos autores é o fazer artístico ou, no segmento em pauta, a criação literária. É certo que no caso dos autores que voluntária ou involuntariamente são associados a identidades específicas ou a conflitos pós-coloniais, como os já citados Édouard Louis ou Scholastique Mukasonga, Gael Faye e Ishmael Beah, os fatos ganham maior peso devido ao desejo desses autores de fazerem uso da literatura como um canal de denúncia de uma determinada condição de opressão ou de subalternidade. Ocorre que o simples fato desses autores não o fazerem por meio de um relato direto, com pouco ou nenhum artifício estilístico, revela que não é desejo deles simplesmente evidenciar realidades, mas sim recriá-las de algum modo.

Ainda que as grandes diásporas contemporâneas, a condição pós-colonial e os dilemas identitários e de reconhecimento ajudem a explicar o fenômeno da emergência do real na literatura, dado o fato provável de que o uso de alegorias tende a enfraquecer o componente de denúncia que os autores pretendem imprimir às suas obras, tais aspectos não explicam a totalidade do fenômeno, uma vez que este não é o caso de autores como Knausgård, cuja trajetória de vida, relatada ao longo da série Minha Luta, está longe do que se poderia classificar como a de um outsider. Sua história de vida é a de um sujeito comum, oriundo de uma família de classe média norueguesa "padrão", filho de pai professor ginasial e mãe enfermeira, cuja trajetória não carrega nada de espetacular ou épico. O que ele narra é uma trajetória essencialmente burguesa, marcada por episódios como crises de reconhecimento típicos da infância, problemas de socialização na escola, conflitos de afirmação próprios da adolescência e da juventude; crises de autoestima; conflitos amorosos; embaraços nos relacionamentos, nos processos de constituição de família e na relação com os filhos; e dilemas profissionais que, no caso do autor em pauta, vão redundar na "descoberta da escrita".

Pela coincidência temporal do lançamento das obras supostamente autobiográficas que projetaram os dois autores europeus, e por explorarem um universo de experiência de vida aparentemente repetitivas e banais, comuns ao mundo burguês, de classe média, globalmente "padronizado", Knausgård e Elena Ferrante têm sido frequentemente comparados entre si. Em um artigo publicado na New Yorker, o crítico Joshua Rothman (2015) observou que:

Tanto em Knausgård como em Ferrante, o embate narrativo que envolve confrontar o passado é sobreposto à resistência e à luta juvenil contra a opressão. São livros sobre jovens que lutam para se libertar do que herdaram, escritos por pessoas mais velhas que lutam para estabelecer um relacionamento mais equilibrado com seus eus mais jovens. A qualidade luminosa desses romances - a sensação de que todo parágrafo, não importa o conteúdo, é vital - é resultado dessa duplicidade. Quando olham para o passado, eles parecem dizer 'eu era jovem e, apesar do meu medo, resisti ao mundo que me foi entregue'. Quando se voltam para o presente, dizem 'estou mais velho e meu passado é o que devo resistir ou aceitar'. Ou talvez haja uma alternativa à resistência ou à aceitação: esses romances parecem estar construindo ideias metafísicas sobre como nossos eus de hoje se 
relacionam com toda a extensão de nossas vidas (ROTHMAN (2015, tradução minha).

A ironia dessa notoriedade rediviva alcançada por esse estilo literário é que para muitos críticos a forma romanesca tendia a desaparecer justamente pelo fato de ser uma forma dominada pelo realismo. Para Adorno (2003), que foi um desses críticos, o fato de os romances virem se conformando a narrativas cada vez mais descritivas, tratando de realidades eminentemente particulares e burguesas, abdicando de qualquer esforço de interpretação do mundo na sua totalidade, estaria levando a um esgotamento do gênero. Isso porque a existência dos indivíduos na sociedade liberal é estandardizada, repetitiva e, portanto, desinteressante; e o romance moderno, ao se constituir como a forma literária mais vinculada a essas formas de existência, com a emergência de autores cada vez mais voltados para a construção de narrativas baseadas nas suas subjetividades particulares, tinha perdido o valor geral essencial da psicologia de um Dostoiévski, por exemplo.

Adorno teceu tais considerações em um ensaio curto, escrito em 1954. De lá pra cá não só o romance resistiu como foi reinventado sob novas formas, tal como a do "realismo mágico" latino-americano, a do novo romance francês e a do romance pósmoderno (PERRONE-MOISÉS, 2016). Ao mesmo tempo, as formas realistas ganharam novos contornos com grande destaque na literatura norte-americana em obras de escritores como John dos Passos, F. Scott Fitzgerald, Faulkner, Hemingway (que incorporou a narrativa jornalística ao romance), Philip Roth, Raymond Carver,
Lucia Berlin e, mais recentemente, jovens autores como Jonathan Franzen e Jonathan Safran Foer.

A concepção de Adorno, entretanto, bebe na fonte do tratado histórico-filosófico A teoria do romance, de Georg Lukács (2000), escrito entre 1914 e 1915 e publicado pela primeira vez em 1920, no qual esse autor interpreta os gêneros literários como consequência de injunções culturais e históricas específicas. Em tal obra, Lukács já havia postulado a fragmentação da totalidade do homem, sendo o gênero romance a expressão dessa fragmentação, considerando que para ele (e posteriormente também para autores com Benjamin e o próprio Adorno) a forma revela o período histórico em que nasce. Mas, ao mesmo tempo, embora reconhecendo que o romance é a forma necessária da modernidade, ele não via com otimismo a sua permanência futura.

\section{Lukács, a fragmentação da totalidade e o realismo}

A relação com a realidade é uma dimensão basilar nas tipologias imaginadas por Lukács (2000) na sua teoria do romance. Conforme a concepção histórico-filosófica desenvolvida por ele, a realidade não se colocava como um problema em um tempo e lugar idealizado que ele concebeu como sendo o mundo grego arcaico, ou seja, o das culturas fechadas, em que tudo era pleno de substância, não havendo separação entre homem e mundo. Com isso, o homem não se achava solitário como único portador de substância, dado que ele estava integrado a um todo universal em que não havia cisão entre interior e exterior, entre o eu e o mundo, entre alma e ação, 
entre ideia e realidade. A epopeia prevalecia então como a forma literária que expressava essa unidade plena do homem integrado ao todo, em que tudo era substância.

Mas eis que a partir de certo momento, o qual da maneira colocada por Lukács (2000) lembra uma espécie de expulsão do paraíso, a plenitude da substância começou a se desvanecer e a essência do sujeito foi perdendo a imanência em relação à vida. Surgiram a filosofia e a tragédia grega, revelando o sujeito contingente na figura do herói como símbolo da autoperfeição apegado às paixões terrenas, começando a distanciar os homens da relação direta com os deuses. Se no mundo arcaico a relação com os deuses era essencial, sendo os heróis sempre guiados por eles para evitar que a realidade os esmagasse, essa relação direta foi se perdendo com o processo de fragmentação do homem alcançando o ápice na modernidade, momento em que os deuses estão totalmente fora do mundo e em que a essência está totalmente afastada da vida

O homem dissociado da totalidade, que perdeu relação com a substância da vida, depara-se finalmente com uma existência marcada por uma solidão insuperável, de um nascer e viver solitários em meio a outros solitários. A "realidade" então se impõe em um mundo em que todos estão condenandos a um isolamento trágico.

Não por outra razão a tragédia permanece na sua forma moderna tendo perdido seu caráter geral e público, individualizando o sujeito e o colocando como herói trágico e solitário, restrito à vida privada, cujo destino inevitável se precipita em meio a relações cotidianas, com familiares e pessoas próximas (WILLIAMS, 2002). O desenrolar de uma tragédia moderna pode se dar no espaço de tempo de um dia, ou mesmo de uma noite, na vida do herói, no qual ninguém escapa de um destino perverso e inevitável, dos quais são exemplos Quem tem medo de Virgínia Woolf?, de Edward Albee, Um bonde chamado Desejo, de Tennesse Williams, e Longa jornada noite adentro, de Eugene O'Neill, textos cuja verdadeira essência é a solidão e a incapacidade de entendimento mútuo dos personagens.

Mas é o romance a forma literária mais adequada a sintetizar em seu conteúdo o percurso dessa alma solitária e cindida, que vai a campo em busca de aventuras que a põem à prova e a colocam no caminho da busca pela própria essência e por uma ideia de totalidade que se perdeu. Não por outra razão, algumas interpretações de A teoria do romance sugerem que, para Lukács, o romance é a forma necessária da modernidade por operar com uma estrutura narrativa voltada para a busca de sentido em um contexto histórico em que o sentido da vida foi perdido:

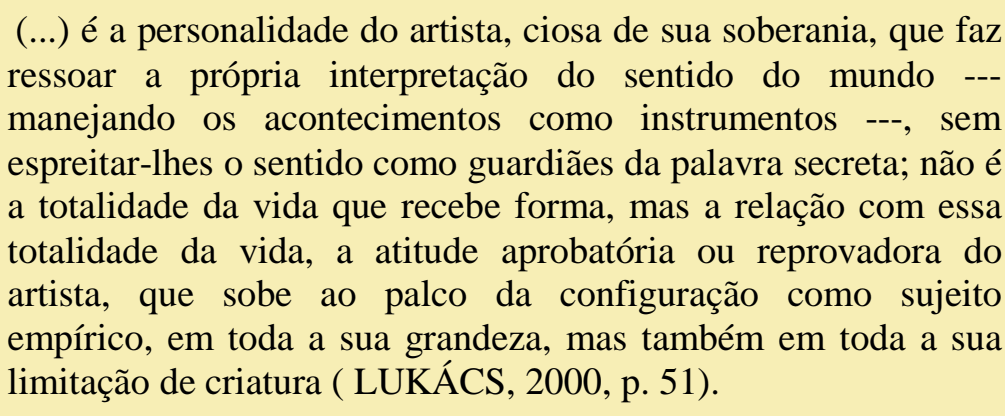

Entretanto, ao analisar os caminhos tomados pelo romance,

Lukács (2000) vai concluir com um prognóstico pessimista acerca 
do potencial de sobrevivência dessa forma literária. Para chegar a essa conclusão, ele começa identificando tipologias cujo ponto de partida é a ideia de que o abandono do mundo por Deus revela-se na inadequação entre alma e obra, entre interioridade e aventura, na ausência de correspondência transcendental para os esforços humanos. Essa inadequação é de dois tipos: ou a alma é mais estreita ou mais ampla do que o mundo exterior, ou seja, a realidade.

O tipo de romance que ele classifica como vinculado ao idealismo abstrato é aquele do demonismo do estreitamento da alma em relação ao mundo. São romances em que os heróis não têm dimensão da realidade e dos seus limites, que sem movem, imbuídos de um deslumbramento demoníaco, perseguindo obsessivamente um mundo idealizado que não encontra correspondência com o real. Dom Quixote é, para Lukács, o exemplo acabado do idealismo abstrato, de total falta de correspondência entre a alma do herói em relação à realidade. Nessa forma de romance, toda vitória sobre a realidade é uma derrota para a alma, já que a enreda cada vez mais, até a ruína, no que é alheio à sua essência (2000).

O segundo tipo de romance identificado por ele é o denominado romantismo da desilusão, sendo Educação Sentimental, de Flaubert, apresentado por Lukács como um paradigma desse tipo de romance, o qual também envolve uma inadequação entre alma e realidade, mas uma inadequação de outro tipo: é a inadequação que nasce do fato de a alma ser mais ampla e mais vasta do que os destinos que a vida concede. Essa forma de romance passa a tratar de uma realidade puramente interior, repleta de conteúdo e mais ou menos perfeita em si mesma, que entra em disputa com a realidade exterior. A vida interior dos heróis dos romances da desilusão tem características próprias, muito mais ricas e dinâmicas do que as possibilidades que se apresentam no exterior. Entretanto, apesar da distância entre o mundo interior e o exterior, o herói do romance da desilusão é imbuído de autoconfiança espontânea, e toma a realidade interior como a única realidade verdadeira, a essência do mundo, partindo para o mundo exterior na busca pela equiparação com o interior mais vasto de possibilidades. Ao final, essa busca se revela uma tentativa inútil, conferindo à composição literária o caráter da desilusão que Lukács atribui a esse tipo de romance.

Há uma substituição no romance da desilusão de uma narrativa fabular e dinâmica que caracteriza o idealismo abstrato pela análise psicológica, em que começa a existir uma tendência à passividade (LUKÁCS, 2000). A obsessão demoníaca de todos os homens nesse tipo de romance é essencialmente psicológica, de modo que as batalhas internas são mais evidentes do que as externas. Porém, ao mesmo tempo, a objetivação dessa obsessão se concretiza nas estruturas da vida social.

Ao contrário do idealismo abstrato, no romance da desilusão, os personagens são conscientes da realidade. Entretanto, eles não se se conformam com o lugar e o destino que lhes são atribuídos socialmente, optando por lutarem por outras possibilidades, mais ricas e mais compatíveis com a vastidão 
interior e plenitude da alma. A narrativa então se desdobra com os protagonistas buscando escapar dos seus destinos restritos e limitados. Mas no desenrolar da trama, a realidade vai se impondo, levando-os a lutarem contra o poder do tempo que fatalmente os levará de volta ao reencontro com a realidade que lhes cabe. Quando o herói, pela sua luta e busca, constata essa impossibilidade de configurar sentido à vida a partir do ideal por ele alimentado, já é tarde demais e o resultado é a desilusão.

Ao tratar do tempo como o fator de discrepância entre o ideal e a realidade, Lukács (2000) tece a seguinte comparação:

$\mathrm{Na}$ epopeia, a imanência do sentido à vida é tão forte que o tempo é por ela superado: a vida ingressa na eternidade como vida, a organicidade aproveitou do tempo apenas a floração, e todo estiolamento e morte foi esquecido e deixado para trás. No romance, separam-se sentido e vida, e portanto, essencial e temporal; quase se pode dizer que toda a ação interna do romance não passa de uma luta contra o poder do tempo. No romantismo da desilusão, o tempo é o princípio depravador: a poesia, o essencial, tem de perecer, e é o tempo, em última instância, que causa esse definhamento (LUKẢCS, 2000, p. 129)

No meio do caminho entre o idealismo abstrato e o romance da desilusão, Lukács vai encontrar o romance de formação ou de educação, cujo tema é a reconciliação do indivíduo problemático com a realidade social concreta. Ou seja, em lugar de se desiludir ao tomar consciência da impossibilidade de escapar da realidade, o herói chega ao final da narrativa se reconciliando com ela. Esse é o caso do romance "Os anos de aprendizado de Whilhelm Meister", de Goethe, no qual o jovem Whilhelm, em seus anos de aprendizado (na juventude), passa por inúmeros infortúnios, os quais acabam se configurando como parte de um aprendizado que leva o sujeito a não se acomodar apenas na reflexão, mas também a agir sobre a realidade como forma de buscar o seu próprio desenvolvimento.

O parâmetro educativo preservado nessa forma e que a distingue claramente do romance da desilusão consiste no fato de que o advento final do herói a uma solidão resignada não significa um colapso total ou a conspurcação de todos os ideais, mas sim a percepção da discrepância entre interioridade e mundo, uma realização ativa da percepção dessa dualidade: a adaptação à sociedade na resignada aceitação de suas formas de vida e o encerrar-se em si e guardar-se para si na interioridade apenas realizável na alma (LUKÁCS, 2000, p. 142-3).

Entretanto, Lukács (2000) conclui constatando que a evolução histórica não teria como ir além do romance da desilusão, não vislumbrando, consequentemente, a possibilidade de surgimento de novos tipos e a sobrevivência do gênero. Mesmo Tolstói, autor que para ele havia tentado romper com os tipos tradicionais do romance, não havia conseguido realizar essa ruptura, dado que os heróis dos seus romances, apesar de revelarem uma mentalidade eminentemente épica ao vislumbrarem uma vida integrada na organicidade das comunidades de homens simples, ligados a uma totalidade representada pela natureza, permaneciam nostálgicos, abstratos e de certo modo permanentemente desafiados por uma realidade que em tudo negava o idealizado.

Lukács, porém, observou que Dostoiévski teria obtido algum sucesso na tentativa de romper com os tipos de romance pautados no embate entre as ideias e o existente, dado que nas suas obras a 
realidade não é desafiada, mas sim contemplada, e as ideias em si se confundem com a ação.

Ao contrário de Lukács (2000), Bakhtin (2015) considerava que o romance não era um gênero em declínio, uma vez que, dado o seu caráter inacabado, aquilo que poderia se constituir como a fragilidade do romance, ou seja, a impossibilidade de realizar o intento de dar forma à totalidade oculta da vida, configura-se como a sua força, uma vez que tal inacabamento nada mais é do que o espelho de uma realidade em mudança constante. Pelo fato de o romance operar com uma atitude mental em que a experiência é um elemento crucial para o desenvolvimento da narrativa, algo que também contribui para uma renovação constante da forma, ele se reafirma em um mundo em crise constante, em que o herói não opera com certezas e verdades absolutas, algo inconcebível na epopeia em que prevalece a memória de um passado absoluto.

Dostoiévski é apresentado por Bakhtin como um exemplo paradigmático de inovação do romance justamente por ele ter encontrado uma maneira de representar na literatura o caráter inconclusivo do homem moderno. Para tal, o recurso utilizado por Dostoiévski foi o que Bakhtin denominou de polifonia, uma espécie de diálogo interno, muitas vezes contraditório, realizado pelos personagens dos seus romances, por meio do qual eles procuram conhecer o outro como forma de conhecer o próprio eu. Nesse sentido, afirma Bakhtin:

Em toda parte é o cruzamento, a consonância ou a dissonância, de réplicas do diálogo aberto com as réplicas do diálogo interior dos heróis. Em toda parte um determinado conjunto de ideias, pensamentos e palavras passa por várias vozes imiscíveis, soando em cada uma de modo diferente (2010, p. 308).

A polifonia não consiste, entretanto, somente de um diálogo entre personagens. Trata-se de uma espécie de intercâmbio de vozes, em que a visão do autor não se impõe a nenhum dos personagens, de modo que, mesmo em diálogos constantes uns com os outros e influências mútuas, cada um consegue manter a sua singularidade e visão de mundo independentes do autor ou dos demais personagens. Isso acabou por legar à forma romanesca uma complexidade e uma riqueza de possibilidades de subjetividades e tipos humanos que, quando bem compreendidos e utilizados, permite aos autores escaparem das armadilhas da padronização e do uso da linguagem ficcional para disseminação de crenças e ideias pré-concebidas. Por essa razão, mais do que uma forma narrativa, Bakhtin identifica no romance polifônico um projeto filosófico em que Dostoiévski procurou valorizar as singularidades dos sujeitos e as infinitas possibilidades de existências humanas, algo que costuma ser negligenciado, por exemplo, em sistemas filosóficos que se propõem a buscar verdades universais.

Tal interpretação contribui para entender a resiliência da forma romanesca, que vem sobrevivendo no tempo e chega ao século XXI ainda impregnada de realismo e de relatos de vivências pessoais e subjetivas, que, mesmo quando parecem comuns ou desinteressantes pelo fato de narrarem realidades ordinárias e sem 
qualquer apelo épico, continuam a atrair leitores, mantendo-se como a forma literária mais popular até os dias de hoje.

\section{A narrativa autoficcional de Knausgård}

Ainda que não citando Bakhtin, Knausgård reverbera uma percepção semelhante em relação a Dostoiévski no que diz respeito ao esforço deste autor em não imprimir as suas ideias e convicções na psicologia dos seus personagens e que caracteriza a polifonia:

A humilhação e o aniquilamento de si próprio são os ideais nos
romances mais importantes de Dostoiévski, e toda grandeza
reside no fato de que esses ideais nunca se realizam no interior
da ação, porque é justamente o resultado da humilhação e do
aniquilamento de si próprio que levou a cabo na condição de
autor. Ao contrário da maioria dos grandes escritores, o próprio
Dostoiévski não aparece nos romances que escreveu. Não existe
nenhum brilhantismo nas frases capaz de fazer com que se
destaque, nenhuma moral derradeira que se deixe apreender, ele
usa todo o engenho e toda a arte para conferir individualidade às
pessoas, e como existem muitas coisas nas pessoas que resistem
à humilhação e ao aniquilamento de si próprias, essa batalha e
essa atividade permanecem sempre mais intensas do que a
passividade da graça e do perdão em que se diluem
(KNAUSGÅRD, 2014, p. 97-98).
Dostoiévski é um autor recorrentemente citado por Knausgård, especialmente durante o período em que enfrentou um bloqueio criativo e passou a questionar a forma tradicional de ficção, com personagens tradicionais, para expressar as suas próprias inquietações. A influência de Dostoiévski é perceptível na série, com destaque para as múltiplas camadas de vozes faladas por ele próprio, como personagem, a cada etapa da sua vida, ou como narrador que procura olhar para si de forma crítica e distanciada.
Mas é na tradição memorialista, que tem como marco o Em busca do tempo perdido, de Marcel Proust, que Knausgård mais pode ser identificado a partir da série Minha Luta. Sendo mais específico, a sua forma narrativa estaria mais próxima do que vem sendo denominado de "autobiografia ficcional”, ou autoficção, no qual os autores abdicam da pretensão de abarcar uma totalidade, optando por fazer um relato parcial e aparentemente insignificante das suas próprias vidas, apresentando para os leitores uma descrição minuciosa de fatos, gestos e objetos do cotidiano (PERRONEMOYSÉS, 2017). A expressão autoficção teria sido utilizada pela primeira vez em 1977 por Serge Dubrovky, na quarta capa do seu livro Le Fils ( $O$ Filho) para descrever um gênero que não era nem diário, por não narrar os acontecimentos do dia a dia em ordem cronológica, nem era estritamente autobiográfico por não narrar a vida inteira do autor, podendo falar do presente social, político e psicológico, mas sempre pela voz do narrador-autor (PERRONEMOYSÉS, 2017).

No caso da série Minha Luta, embora muito centrada no autor, não é uma obra estritamente autorreferente, dado que o entorno e a realidade psicológica dos demais personagens são parte da narrativa. Em um esforço de aproximação dos romances da série Minha Luta com as tipologias de romance identificadas por Lukács (LUKÁCS, 2000), é possível observar que o percurso de Knåusgard como personagem segue uma trajetória típica do herói dos "romances de formação", comuns entre os séculos XVIII e XIX. Isso porque o herói da série (no caso ele próprio) é visivelmente um 
idealista em processo de aprendizado e conciliação com a realidade, buscando um sentido para a vida em luta contínua pela concretização do seu ideal de ser escritor.

Ademais, o esforço de aprendizagem e o resultado do ideal perseguido não se materializa no interior da narrativa, mas no próprio leitor, tendo em vista que esse ideal que ele persegue é justamente a obra que o leitor tem em mãos no tempo real da leitura. Pode-se considerar, portanto, que o leitor acaba sendo um personagem da obra, uma vez que ele é parte essencial do desenrolar do romance e da sua repercussão, ainda mais quando se verifica que, no sexto e último tomo (ainda não publicado no Brasil), Knausgård vai tratar da recepção dos cinco tomos anteriores pelo público e pelos familiares e amigos expostos como personagens ao longo da série.

Ou seja, a obra se realiza em tempo real. Nos termos definidos por Lukács, o que o leitor tem em mãos no real instante em que lê é a materialização do ideal perseguido pelo herói do romance ou o resultado de sua “aprendizagem”. Não há desilusão nem idealismo abstrato em choque com a realidade, mas sim um processo de aprendizado que dá a impressão de não se encerrar com a obra.

Vale ainda destacar que tal tentativa de enquadramento da série Minha Luta à tipologia proposta por Lukács é bastante relativa, uma vez que a obra em pauta é mais que tudo um produto do seu tempo, que incorpora eminentemente características próprias dos romances modernos, marcados por diálogos psicológicos internos em que o autor monologa consigo mesmo sobre sua existência, desejos, angústias e impressões sobre coisas e pessoas que o cercam. Além disso, ela reflete uma sociedade em que a hiperexposição é a tônica, em que faz parte da conduta geral acompanhar e expor vidas privadas nas mídias sociais digitais, ainda que conformadas a determinados simulacros.

Por essa participação do autor e do leitor na obra, os limites entre o real e a ficção são permanentemente postos em xeque, reflexo de uma sociedade que efetivamente já não reconhece mais esses limites, transitando permanentemente por essas fronteiras.

O autor inicia sua narrativa, logo no primeiro livro da série, motivado, segundo ele mesmo, por uma necessidade pessoal, após um longo período de bloqueio criativo, de escrever sobre a morte e relação com o seu pai. A opção pela forma autoficcional foi justificada por ele da seguinte forma em um artigo publicado no The Guardian (2016):

Eu não queria escrever sobre a relação entre um pai e um filho. Eu queria escrever sobre meu pai e eu. Eu não queria escrever sobre uma casa onde um homem vivia com uma mulher idosa, algo como uma variação de O Fantasma, mas sobre aquela casa em particular e a realidade concreta que existia dentro dela (tradução minha).

O enredo é simples e pode ser resumido em algumas poucas linhas. Knausgård é o caçula de um casal com dois filhos, que cresce em um ambiente familiar relativamente estável, mas muito marcado pela autoridade paterna, um homem taciturno, de humor instável, propenso a ataques de fúria que sempre se voltava contra os filhos. Os pais se separam quando o autor se encontrava na 
adolescência. Daí em diante, desdobram-se os problemas de adaptação ao novo contexto da separação dos pais, a descoberta da sexualidade, problemas familiares, escolhas profissionais, primeiros amores, a opção pela escrita, até a chegada à vida adulta, com casamento e filhos. Logo nas primeiras páginas do terceiro tomo, no qual a narrativa se concentra no relato das memórias da infância até a adolescência, o autor faz uma breve caracterização dos pais que permite situar o lugar social de onde vem o autor:

Hoje os dois têm vinte e cinco anos, e têm a vida inteira pela frente. Trabalho próprio, casa própria, filhos próprios. Os dois estão juntos, e o futuro que almejam pertence a eles. Será mesmo? Os dois nasceram no mesmo ano, 1944, e pertenciam à primeira geração do pós-guerra, o que por diversos motivos representava uma certa novidade, em boa parte porque a trajetória de vida deles era uma das primeiras no país a desenrolar-se em uma sociedade planejada em grande escala. Os anos 1950 foram a época do desenvolvimento dos departamentos - o departamento educacional, o departamento de saúde, o departamento social, o departamento de estradas - e também dos escritórios e indústrias, que promoveram um grande processo de centralização que, num curto espaço de tempo, teve grandes consequências na forma como as vidas eram vividas. $\mathrm{O}$ pai dela, nascido no início do século XX, tinha sido criado na fazenda onde ela cresceu, em Sørbøvåg, Ytre Sogn, e não tinha formação nenhuma. $\mathrm{O}$ avô dela vinha de uma das ilhas do mar um pouco além, provavelmente como o pai e o avô dele. A mãe dela tinha sido criada em uma fazenda em Jølster, a uns cem quilômetros de distância, ela também não tinha formação nenhuma, e a árvore genealógica da família na região remontava até o século XVI. A família dele encontrava-se num lugar um pouco mais elevado na escala social, no sentido de que tanto o pai como tio haviam completado o ensino superior. Mas eles também moravam no mesmo lugar onde os pais tinham nascido, ou seja, em Kristiansand. A mãe dele, que não tinha formação nenhuma, era de Åsgårdstrand, o pai era prático e também havia policiais na família. Quando conheceu o marido, os dois mudaram para a cidade natal dele. Esse era o padrão. A mudança que se operou nos anos 1950 e 1960 foi uma verdadeira revolução, mas não teve a violência, a irracionalidade tão comum nas revoluções. Não apenas os filhos de pescadores e agricultores, trabalhadores da indústria e do comércio passaram a frequentar a universidade e a diplomar-se professores, e psicólogos, historiadores e sociólogos, mas também a fixar residência em lugares muito distantes da região onde a família morava. $\mathrm{O}$ fato de que agiam como se fosse a coisa mais natural do mundo diz um bocado sobre o espírito da época. O espírito da época vem de fora, mas influencia o lado de dentro. Todos são iguais para ele, mas ele não é igual para todos. Para uma jovem dos anos 1960 parecia totalmente absurda a ideia de casar-se com um rapaz da vizinhança e passar o resto da vida no mesmo lugar. Ela queria sair! Queria ter uma vida própria! A mesma coisa valia para os irmãos e as irmãs dela, e assim era nas famílias por todo o país. Mas por que essa vontade? De onde vinha essa convicção? Enfim, de onde vinha a novidade? Na família dela não havia nenhuma tradição parecida; o único que tinha viajado era Magnus, o irmão do pai, que tinha ido para os Estados Unidos em função da pobreza na pátria natal, mas a vida que tinha vivido por lá era a mesma que tinha vivido em Vestlandet. Para o jovem pai dos anos 1960 a situação era outra, na família dele esperavam que terminasse os estudos, mas não talvez que casasse com a filha de um pequeno agricultor de Vestlandet e fosse morar em um loteamento nos arredores de uma pequena cidade de Sørlandet (KNAUSGÅRD, 2015, p. 09$10)$.

O que se infere da narrativa é que Knausgård advém de uma trajetória familiar recém-saída do rural, de um núcleo familiar direto que é parte da primeira geração do pós-guerra beneficiária da chamada Golden Age, caracterizada pelo elevado crescimento econômico global, especialmente norte-americano e europeu, e pela consolidação do Estado de Bem-estar social. Ele é filho, portanto, de uma classe média europeia típica, que conquistou um nível educacional um pouco melhor do que a dos pais e ascendeu socialmente muito em decorrência das políticas públicas 
distributivas e de bem-estar. Sua ascendência familiar é parte de um segmento de classe que reconhece o valor dos signos culturais e intelectuais, mas que não possuem todas as ferramentas para se apropriarem desses signos, os quais já eram incorporados naquela altura permeados e atravessados por signos da cultura de massa ou da cultura pop, especialmente a norte-americana.

Toda a história é narrada com um impressionante nível de precisão e riqueza de detalhes de fatos e coisas, de situações corriqueiras e banais, as quais aparecem até mesmo em meio a digressões filosóficas ou intelectuais sobre a condição humana e sobre a escrita. O trecho que segue, no qual ele mistura descrições de passeios e cuidados com a sua primeira filha, ainda bebê, e reflexões sobre Dostoiévski, é ilustrativo da forma com ele introduz tais estruturas descritivas aos seus romances:

Logo passei a dominar tudo o que dizia respeito a uma criança pequena, não tinha nada que eu não fizesse com ela, passeávamos por toda parte, mas independente de onde fôssemos, e independente da enorme ternura que eu sentia por Vanja, a sensação e aborrecimento e passividade era grande. Era importante conseguir que ela dormisse para que eu pudesse ler e fazer com que os dias passassem para riscá-los do calendário. Conheci até os cafés mais remotos da cidade, e não havia praticamente nenhum banco de parque onde eu mais cedo ou mais tarde não tivesse me sentado com um livro na mão e um carrinho de bebê na outra. Era Dostoiévski o que eu tinha comigo, primeiro Os demônios, depois Os irmãos Karamázov. Foi assim que reencontrei a luz. Mas não era a luz sublime, clara e pura de Hölderlin, em Dostoiévski não havia alturas, não havia montanhas, não havia perspectivas divinas, tudo se passava na esfera humana e vinha envolvido na atmosfera pobre, suja, doentia e quase infecta de Dostoiévski, que nunca estava longe da histeria. Nesse ponto estava a luz. Esse era o lugar divino. Mas seria um lugar desejável? (KNAUSGÅRD, 2014, p. 74-5).
Aparecem no romance várias citações e digressões acerca de autores e intelectuais diversos, que vão desde os já citados Dostoiévski e Holderlin, passando por Tolstói, Freud, Nietzsche, Thomas Mann, Milan Kundera, Hemingway, Knut Hamsun, dentre outros. Evidencia-se uma preferência por autores europeus e norteamericanos, mas ao refletir sobre os rumos do que ele considera como vícios de determinadas formas fixas dominantes no seu território cultural literário, arrisca refletir sobre as possibilidades abertas por outros territórios literários, fora da Europa:

Outra diferença que eu tinha notado era que os romances europeus em geral tinham um único acontecimento, que tudo seguia por um mesmo trilho, enquanto os romances sulamericanos tinham uma grande variedade de trilhos diferentes e secundários e, comparados aos romances europeus, praticamente explodiam com a quantidade de acontecimentos. Um dos meus romances favoritos era Cem anos de solidão, de García Márquez, mas $\mathrm{O}$ amor em tempo de cólera também me parecia incrível. (...) Mas e quanto aos meus próprio escritos? (...) Eu só tinha um mundo, e era a respeito desse mundo que eu precisava escrever. Pelo menos naquele momento. Mas tentei levar comigo a fertilidade de García Márquez. A miríade de histórias também (KNAUSGÅRD, 2016, p. 387).

Mas não só são citadas referências daquilo que pode ser considerado como "alta cultura", pois toda a obra é matizada por referências da cultura pop, com destaque para uma vasta gama de artistas do pop-rock citados ao longo da série, que vão do Led Zeppelin, The Cure, The Smiths, passando por Roxy Music, dentre outras tantas bandas alternativas que circulavam no mercado entre os anos 1970 e 1980. Isso sem falar na relação com os quadrinhos e das referências e descrições minuciosas de pequenos objetos e 
marcas de produto, da mesma maneira que fazia a Pop Art nas artes plásticas, um artifício que parece ser utilizado para dar concretude ao relato. Aliás, vale destacar que a inserção do autor no mundo da leitura começa justamente pelos quadrinhos, fenômeno característico da sua geração:

Mas as histórias em quadrinho eram uma coisa só minha, e a minha mãe nunca tinha sequer olhado para elas. E de repente eu estava proibido de ler? Isso por acaso não era totalmente injusto? Chorei, me enfureci, voltei para falar com ela e disse que ela não tinha o direito de me boicotar, mas ao mesmo tempo eu sabia que tinha perdido a batalha, ela estava decidida e se eu não parasse de protestar ela talvez contasse tudo para o meu pai, contra quem eu não tinha nenhuma defesa. Devolvi as histórias em quadrinho que eu tinha pegado emprestadas e as outras foram jogadas no lixo. No dia seguinte fomos para a biblioteca, fizemos nossos cartões e pronto, a partir daquele momento tudo se resumiria aos livros. Toda quarta feira eu descia a biblioteca de Arendal com uma sacola cheia de livros em cada mão. (...) li os muitos livros de Júlio Verne e os meus favoritos eram Vinte mil léguas submarinas e Volta ao mundo em oitenta dias (...) Li também o Conde de Monte Cristo e os Três Mosqueteiros, Vinte anos depois e Tulipa Negra. Li O pequeno Lorde, li Oliver Twist e David Copperfield, li Sem Família e A Ilha do Tesouro e o livro do capitão Marryat, que eu adorava e reli inúmeras vezes, porque este livre era meu, e não retirado da biblioteca. Li O grande motim, os livros de Jack London e livros sobre beduínos e caçadores de tartarugas, passageiros clandestinos e pilotos de corrida (KNAUSGÅRD, 2015, pp 271-3).

Diante de uma trajetória pessoal tão comum a padrões de classe média, o que explicaria o interesse do público em geral pela tematização literária dessa experiência de vida, refutando os prognósticos adornianos de que ao enveredar por realidades eminentemente particulares e burguesas o romance era um gênero fadado ao esgotamento? Bourdieu (2001) oferece algumas pistas para entender o fenômeno ao mostrar que desde a época romântica o interesse pela pessoa do escritor e do artista se ampliou. A vida do escritor se tornou ela própria uma espécie de obra de arte, ingressando, enquanto tal, na narrativa literária, sendo $O$ Sofrimento do Jovem Werther, de Goethe, um caso exemplar. O culto romântico da biografia passou a ser parte integrante de um sistema de ideias em que a concepção de criação se torna irredutível da pessoa do artista. Desde então, esse fenômeno tem sido facilmente observado em todos os campos artísticos, tendo se disseminado ainda mais com a emergência da cultura pop.

Mas o próprio Knausgård ensaia uma resposta para tal pergunta. Para ele, transformar a própria história de vida em romance realista (ou autoficção) é consequência do fato de que a ficção tradicional, com personagens fictícios, não é mais capaz de atribuir sentido ao mundo e modificá-lo, uma vez que no mundo de hoje o contato com o real se perdeu, dado que as pessoas transformaram todas as dimensões das suas vidas em fantasia. Nesse sentido, uma vez que tudo se transformou em ficção, ele optou por fazer uso de recursos da ficção para narrar fatos reais, de modo a “combater a ficção com ficção" ((KNAUSGÅRD, 2013, p. 259). E fez isso, partindo do pressuposto de que o papel da escrita é muito mais destruir do que criar:

Escrever é mais destruir do que criar. Rimbaud sabia disso melhor que ninguém. Digno de nota não é que ele tenha chegado tão inacreditavelmente jovem a esse insight, mas que tenha aplicado isso à sua própria vida. Para Rimbaud, tudo dizia respeito à liberdade, tanto na escrita como na vida, e só porque a liberdade tinha um papel dominante é que ele podia deixar a 
escrita em segundo plano, ou talvez até tivesse que deixar a escrita em segundo plano, pois ela também se tornou para ele um limite que deveria ser destruído. Liberdade é igual a destruição mais movimento (KNAUSGÅRD, 2013, p. 230).

Essa perspectiva destruidora (ou demoníaca) como Knausgård entende romance é um exemplo daquilo que Adorno (2003) denominou de epopeias negativas, ou seja, "romances em que a subjetividade liberada é levada por sua própria força de gravidade a converter-se em seu contrário" (KNAUSGÅRD, 2013, p. 62)

Se assim for, a proposta de Knausgård ao oferecer ao leitor um relato visceral e bastante íntimo de sua própria vida, fazendo uso de recursos estilísticos da ficção para explorar a própria realidade, teria por objetivo produzir idealmente um efeito contrário, de destruição da ficção que hoje perpassa todas as dimensões das relações humanas, trazendo seus leitores para mundo concreto, o mundo das coisas. Nesse aspecto, o recurso utilizado, de narração da própria intimidade é o mais propício em tempos em que o compartilhamento de simulacros da vida pessoal, seja em reality shows, seja em redes sociais, sempre encontra forte e garantida audiência, com a diferença que no caso da série Minha Luta a intimidade relatada pelo autor não possui qualquer glamour ou alegoria: trata-se da vida concreta, como ela é.

\section{Considerações Finais}

A boa recepção que os romances realistas vêm encontrando nos últimos anos não é obra do acaso, tendo em vista a abundância de imagens e notícias que se espalham sem que ninguém tenha mais certeza do que é real e do que é falso. No plano individual, com as possibilidades de compartilhamento sem mediações de conteúdos por qualquer pessoa pelas redes sociais abriu um flanco de construção de simulacros, em que predominam imagens idealizadas de felicidade. Trata-se do reflexo de um tempo em que a fantasia e a falsificação legitimada perpassam todas as esferas da vida.

Nesse contexto, aproximar a ficção do real pode ser interpretado como uma forma de contrapor os simulacros com dimensões da realidade concreta em linguagem romanceada, algo como "combater ficção com ficção", conforme palavras do próprio Knausgård. Essa proposição se assemelha à afirmação de Barthes (KNAUSGÅRD, 2005), apresentada na introdução deste artigo, de que criar e ficcionalizar mundos é entrever uma "saída para o Real" e que os romances são o melhor caminho para tal, tendo em vista que a forma romanesca, mesmo de gênero realista, memorialista ou de autoficção, não requer compromisso literal com os fatos ou com a realidade. Pelo contrário: ela requer a "deformação da memória".

A maior parte dos romances realistas contemporâneos vem apostando em narrativas em contextos de diferenças, sejam elas identitárias, sejam elas de mundos povoados pelos dramas do póscolonialismo. O que se destaca em Knausgård é o fato de ele narrar uma realidade comum ao contexto da classe média contemporânea, que, pelas suas características de homogeneidade, pode ser reconhecida como muito semelhante em qualquer parte do mundo, sendo ela própria a formar o público majoritário de leitura de romances. Ao romancear a sua própria história e ter como leitor um 
tipo de público que vive experiências semelhantes, mas que, mesmo assim, permite-se surpreender com o que é narrado, talvez pelo fato de a série Minha Luta abordar situações que costumam ser escamoteadas no contexto de superexposição seletiva e fantasiosa em que vivemos, Knausgård procura oferecer ao leitor a oportunidade de reaprender a lidar com o real.

Por fim, vale destacar que o fenômeno contemporâneo do realismo corrobora a potencialidade de adaptação do romance a qualquer tempo, ainda que operando com sinais contrários ao que lhe é contemporâneo (mais propensa à destruição do que à criação, em que prevalece o demoníaco, em termos lukacsianos, como "expressão simbólica" da impossibilidade da harmonia no mundo), deixando claro que a forma romanesca resiste e continua a se reinventar como forma narrativa. Isso talvez possa ser explicado pela necessidade de se compreender a vida a partir de relatos de experiências alheias, inclusive aquelas que estão em desacordo com o tempo histórico, tendo em vista que, na impossibilidade de se compreender as totalidades universais, o leitor de um romance vai juntando fragmentos como forma de se sentir menos solitário e de entender a si próprio e sua condição do mundo.

\section{BIBLIOGRAFIA}

ADORNO, Theodor W. Notas de Literatura I. Edição: 2 ed. São Paulo: Editora 34, 2003

BAKHTIN, Mikhail. Teoria do Romance I. A Estilística. $1^{\text {a }}$ ed. São
Paulo: Editora 34, 2015.

BAKHTIN, Mikhail. Problemas da Poética de Dostoiévski. Edição: 5 ed. São Paulo: Forense Universitária, 2010.

BARTHES, Roland. A Preparação do Romance - Volume 1. Edição: $1^{\text {a }}$ ed. São Paulo: WMF Martins Fontes, 2005.

BOURDIEU, Pierre. "Campos de poder, campo intelectual e habitus de classe", In: A Economia da Trocas Simbólicas. Ediçao: $5^{\text {a }}$ ed. São Paulo: Perspectiva, 2001

FOSTER, Hal. O Retorno do Real. Edição: $1^{\mathrm{a}}$ ed. São Paulo: Cosac \& Naify, 2014.

KNAUSGÅRD, Karl Ove. A Descoberta da Escrita. Edição: 1 ed. São Paulo: Companhia das Letras, 2017.

KNAUSGÅRD, Karl Ove. A Ilha da Infância. Edição: 1 ed. São Paulo: Companhia das Letras, 2015.

KNAUSGÅRD, Karl Ove. A Morte do Pai. Edição: 1 ed. São Paulo: Companhia das Letras, 2013.

KNAUSGÅRD, Karl Ove. Um Outro Amor. Edição: 1 ed. São Paulo: Companhia das Letras, 2014.

KNAUSGÅRD, Karl Ove. Karl Ove Knausgaard: the shame of writing about myself. Londres: The Guardian, 26 fev, 2016 Disponível

<https://www.theguardian.com/books/2016/feb/26/karl-ove-

knausgaard-the-shame-of-writing-about-myself $>$. Acesso em: 25 ago 2018

KNAUSGÅRD, Karl Ove. Uma Temporada no Escuro. Edição: 1 ed. São Paulo: Companhia das Letras, 2016. 
KNAUSGÅRD, Karl Ove. Writing my strugle: um exchange. Entrevista Concedida a Maurício Meireles. Nova York: Paris Review, Winter 2014. Entrevista Concedida a James Wood. Disponível

$<$ https://www.theparisreview.org/miscellaneous/6345/writingemmy-struggle-em-an-exchange-james-wood-karl-ove-

knausgaard>. Acesso em: 25 ago 2018

LUKÁCS, Georg. A Teoria do Romance. Edição: 2 ed. São Paulo: Editora 34, 2000

PERRONE-MOISÉS, Leyla. Leyla Perrone-Moisés fala sobre a resistência da ficção - 12/02/2017 - Ilustríssima. São Paulo: Folha de São Paulo. Entrevista Concedida a Maurício Meireles. Disponível em:

<http://www1.folha.uol.com.br/ilustrissima/2017/02/1857605-leylaperrone-moises-fala-sobre-a-resistencia-da-ficcao.shtml>. Acesso em: 26 ago 2018

PERRONE-MOISÉS, Leyla. Mutações da Literatura. Século XXI. Edição: 1 ed. São Paulo: Companhia das Letras, 2016.

ROTHMAN, Joshua. Knausgaard or Ferrante? Nova York: The New Yorker, 25 Mar 2015. Disponível em: <https://www.newyorker.com/culture/cultural-

comment/knausgaard-or-ferrante>. Acesso em: 25 ago 2018.

WILLIAMS, Raymond. Tragédia Moderna. Edição: $1^{\mathrm{a}}$ ed. São Paulo: Cosac \& Naify, 2002. 